\title{
POLYMORPHISM OF DNA REPAIR GENE XPD Lys751GIn AND CHROMOSOME ABERRATIONS IN LYMPHOCYTES OF THYROID CANCER PATIENTS EXPOSED TO IONIZING RADIATION DUE TO THE CHORNOBYL ACCIDENT
}

\author{
V.M. Shkarupa ${ }^{1, *}$, O.Y. Mishcheniuk ${ }^{1}$, S.O. Henyk-Berezovska ${ }^{2}$, V.O. Palamarchuk ${ }^{3}$, S.V. Klymenko \\ ${ }^{1}$ State Institution «National Research Centre for Radiation Medicine of National Academy of Medical \\ Sciences of Ukraine», Kyiv 04050, Ukraine \\ ${ }^{2}$ State Institution «Institute of Hereditary Pathology of National Academy of Medical Sciences of Ukraine, \\ Lviv 79000, Ukraine \\ ${ }^{3}$ Ukrainian Scientific and Practical Center of Endocrine Surgery, Transplantation of Endocrine Organs \\ and Tissues of the Ministry of Health of Ukraine, Kyiv 01021, Ukraine
}

The aim of this work was to analyze the relationship between polymorphisms of DNA repair gene XPD Lys751Gln and frequency and spectrum of chromosome aberrations in the culture of peripheral blood lymphocytes of thyroid cancer (TC) patients having been exposed to ionizing radiation due to the Chornobyl accident. Materials and Methods: XPD Lys751Gln polymorphisms were detected by polymerase chain reaction in 102 TC patients including 38 patients exposed to ionizing radiation due to Chornobyl disaster (Chornobyl recovery workers, evacuees, and the residents of contaminated areas), 64 patients without history of ionizing radiation exposure and 45 healthy residents of Ukraine as control group. Results: In homozygous carriers of the minor allele XPD GIn751GIn, exposed to ionizing radiation, the significantly increased risk of TC (odds ratio $=3.66 ; p=0.03 ; 95 \%$ confidence interval 1.04-12.84) was found. Among evacuees and residents of contaminated areas, homozygous carriers of the minor allele variants of XPD gene were characterized by the high level of spontaneous chromosome aberrations. TC patients without history of ionizing radiation exposure, being homozygous carriers of the allele XPD Lys751Lys, had significantly reduced frequency of chromosome-type aberrations. Conclusions: The carriage of homozygous minor allele of DNA repair gene XPD GIn751GIn is a risk factor for TC in persons from Ukrainian population exposed to ionizing radiation and is associated with the increased levels of chromosomal instability. This article is a part of a Special Issue entitled "The Chornobyl Nuclear Accident: Thirty Years After".

Key Words: XPD gene polymorphisms, thyroid cancer, Chornobyl disaster, chromosome aberrations.

The diversity of XPD protein role in transcription processes and DNA repair status underlines the value of a polymorphic gene status in a susceptibility to cancer pathology [1-5]. However, the role of XPD polymorphisms in the pathogenesis of malignant tumors remains controversial. One and the same alleles of polymorphic gene XPD may have the favorable or protective effect in terms of oncogenesis, depending on the ethnicity of the population, the type of tissue, from which the tumor develops, and the impact of environmental factors [2-9]. For these reasons, the literature data on the role of polymorphisms of gene $X P D$ in cancer risk and tumor progression, especially under the impact of ionizing radiation (IR), are ambiguous and further research is required.

XPD is an important component of nucleotide excision repair (NER) and is able to resist radiation-induced DNA damage [10]. DNA repair gene polymorphisms result in significant differences in the efficiency of repair of already existing DNA damage. The changes of functional activity of specific proteins that function

Submitted: August 01, 2016.

*Correspondence: E-mail: Shkarupa_vlad@bigmir.net Abbreviations used: IR - ionizing radiation; IRS - individual radiosensitivity; NER - nucleotide excision repair; NPP - nuclear power plant; PCR - polymerase chain reaction; TC - thyroid cancer. in the reparative systems, potentially lead to mutagenesis. However, the role of individual polymorphic DNA repair system markers in chromosome mutagenesis can not be definitively established. Search for important genetic markers of individual genotoxic sensitivity to radiation effects among highly polymorphic genes today also gave not definitive results [11-17]. Among the possible reasons for this, it was indicated the use of different approaches for the assessment of the mutagenesis (the measure different metrics: aberrations of chromosomes, micronuclei, DNA strand breaks) in populations, that have the different distribution of genotypes of the polymorphic markers [18]. However, the study of the relationship of polymorphisms of genes with the level of chromosomal damages in the cohorts of persons exposed to IR, may increase the sensitivity of cytogenetic biomarkers as the indicators of the genotoxic effects, as well as may help in the identification of the risk groups.

IR is a causative factor of the radiogenic thyroid cancer (TC). According to a result of large-scale radiation and epidemiological studies, the frequency of the TC among of various contingents of the population exposed to radiation as a result of the Chornobyl accident is increasing. In several studies was found the relationship between of high level of the chromosomal aberrations in the culture of peripheral blood lym- 
phocytes of persons exposed to IR and the risk of the developing of the TC [19].

The aim of this work was to analyze the relationship between polymorphisms of DNA repair gene XPD Lys751GIn and frequency and spectrum of chromosome aberrations in the culture of peripheral blood lymphocytes of TC patients exposed to IR due to the Chornobyl accident.

\section{MATERIALS AND METHODS}

Genotyping of polymorphisms XPD Lys751GIn was performed by polymerase chain reaction (PCR) with electrophoretic visualization of PCR products in $3 \%$ agarose gel in 102 TC patients. 38 TC patients exposed to IR due to Chornobyl accident created the group I. Among them, there were 10 cleanup workers at the Chornobyl nuclear power plant (participants in liquidation of the Chornobyl nuclear power plant (NPP) accident consequences, group IA); and 28 evacuees and residents from areas contaminated with radionuclides (group IB). To the group II we included 64 TC patients without history of IR exposure. The control group was selected from Ukrainian population and accounted 45 persons without cancer. Analysis of the association between the XPD Lys$751 \mathrm{Gln}$ polymorphism and frequency and spectrum of chromosome aberrations (metaphase analysis of chromosomal aberrations in peripheral blood lymphocyte cultures) was performed in 32 TC patients, who had not received chemotherapy or radiotherapy. On average, 200 metaphases were analyzed (100500 ) of the first mitosis per person. Differential counting of chromosome- and chromatid-type aberrations was conducted. The patients were treated in National Research Center for Radiation Medicine of National Academy of Medical Sciences of Ukraine. The study has been performed in accordance with ethics rules for biomedical research. All patients gave an informed consent for the participation in the study.

Compliance with Hardy - Weinberg equilibrium was assessed using Fisher's exact test. Odds ratio (OR) was assessed using logistic regression analysis for the three models of inheritance: multiplicative, additive, and dominant. For frequency and spectrum of chromosomal aberrations mean values and their standard error $(\mathrm{M} \pm \mathrm{m})$ were calculated. Estimation of group frequencies of chromosomal aberrations was calculated by averaging individual frequencies for individuals with certain genotype. Intergroup differences of cytogenetic parameters were evaluated using Fisher's exact test.

\section{RESULTS AND DISCUSSION}

Previously, we have investigated features of the relationship between the XPD Lys751G polymorphism and the risks of TC development in persons exposed to IR after Chornobyl disaster [20]. In comparison with the previous work, in this study we increased the number of patients in the control group, these results are shown in Table 1 and Table 2.
In the total group of TC patients, regardless of history of radiation exposure, the distribution of genotypes corresponded to Hardy - Weinberg equation. Conversely, among TC patients without influence of IR in history (group II), the distribution of genotypes did not meet Hardy - Weinberg equation (Table 1).

Table 1. Distribution of individual gene polymorphisms Lys751Gln XPD, the frequency of the variant allele of the gene $X P D$, and the genotypes distribution matching Hardy - Weinberg equation

\begin{tabular}{|c|c|c|c|c|c|}
\hline \multirow[b]{2}{*}{ Groups } & \multicolumn{4}{|c|}{ XPD genotype, n (\%) } & \multirow[b]{2}{*}{$\begin{array}{c}\text { Hardy - } \\
\text { Weinberg } \\
\chi^{2}, p\end{array}$} \\
\hline & Lys751Lys & Lys751Gln & Gln751Gln & $\begin{array}{c}\text { V allele } \\
\text { (751GIn) } \\
\text { frequency }\end{array}$ & \\
\hline TC (all pa- & $31(30.39)$ & $55(53.92)$ & $16(15.69)$ & 0.43 & 1.07 \\
\hline $\begin{array}{l}\text { tients), } n=102 \\
\text { I, } n=38\end{array}$ & $11(28.95)$ & $17(44.74)$ & $10(26.31)$ & 0.49 & $\begin{array}{c}p=0.30 \\
0.42\end{array}$ \\
\hline $\mathrm{IA}, \mathrm{n}=10$ & $1(10.00)$ & $3(30.00)$ & $6(60.00)$ & 0.75 & $\begin{array}{c}p=0.52 \\
0.40\end{array}$ \\
\hline $\mathrm{IB}, \mathrm{n}=28$ & $10(35.71)$ & $14(50.00)$ & 4 (14.29) & 0.39 & $\begin{array}{c}p=0.53 \\
0.06\end{array}$ \\
\hline II, $\mathrm{n}=64$ & $20(31.24)$ & $38(59.38)$ & $6(9.38)$ & 0.39 & $p=0.80$ \\
\hline $\begin{array}{l}\text { Control, } \\
n=45\end{array}$ & $20(44.44)$ & $21(46.67)$ & $4(8.89)$ & 0.32 & $\begin{array}{c}0.21 \\
p=0.65\end{array}$ \\
\hline
\end{tabular}

Table 2. Association of XPD gene Lys751GIn polymorphism with risk of TC

\begin{tabular}{|c|c|c|c|}
\hline \multirow[t]{2}{*}{ Groups } & $\begin{array}{c}\text { Multiplicative } \\
\text { model }\end{array}$ & Additive model & Dominar \\
\hline & \multicolumn{3}{|c|}{ OR; $95 \%$ confidence interval $(\mathrm{Cl}) ; p$ value } \\
\hline TC (all pa- & Allele Lys751 & Lys751/Lys751 & Lys751/Lys751 \\
\hline tient & $0.64(0.38-1.08)$ & $0.68(0.26-1.13)$ & + Lys751/Gln751 \\
\hline 102) vs & Allele Gln751 & Lys751/Gln751 & $0.52(0.16-1.67)$ \\
\hline group & $1.56(0.93-2.64)$ & $1.34(0.66-2.70)$ & $\mathrm{G} \ln 751 / \mathrm{G} \ln 751$ \\
\hline$(n=45)$ & $p=0.09$ & $\begin{array}{r}\mathrm{G} \ln 7 \\
1.91 \\
p\end{array}$ & $\begin{array}{c}1.91(0.60-6.07] \\
p=0.27\end{array}$ \\
\hline$(\mathrm{n}=$ & Allele Lys751 & Lys & Lys7 \\
\hline vs co & $0.50(0.27-0.94)$ & 0.51 & + Lys \\
\hline \multirow[t]{4}{*}{ group $(n=45)$} & Allele Gln751 & Lys & 0.27 \\
\hline & $2.00(1.06-3.75)$ & 0.93 & $\mathrm{G} \ln 7$ \\
\hline & $p=0.03$ & Gln & 3.66 (1. \\
\hline & & $\begin{array}{r}3.66(1 . C \\
p=\end{array}$ & \\
\hline II $(\mathrm{n}=$ & Allele Lys751 & Lys751/ & Lys \\
\hline vs control & $0.74(0.42-1.31)$ & $0.57(0.26-1.25)$ & + Lys751/Gln751 \\
\hline \multirow[t]{4}{*}{ group $(n=45)$} & Allele GIn751 & Lys751/GIn751 & $0.94(0.25-3.55)$ \\
\hline & $1.35(0.76-2.38)$ & $1.67(0.77-3.61)$ & $\mathrm{G} \ln 751 / \mathrm{G} \ln 751$ \\
\hline & $p=0.30$ & $G \ln 751 / G \ln 751$ & $1.06(0.28-4.00)$ \\
\hline & & $\begin{array}{c}1.06(0.28-4.00) \\
p=0.26\end{array}$ & $\rho$ \\
\hline
\end{tabular}

Analysis of the literature and comparison of the results showed that the frequency of the variant allele $X P D 751 \mathrm{GIn}$ in the group IB and group II did not differ by this parameter in persons without cancer from Poland $-0.39,0.39$ and 0.38 , respectively [9]. Differences in frequency of polymorphic allele of gene XPD 751GIn in combined group of persons (group I) exposed to IR as a result of the Chornobyl accident are statistically not significant compared to the group II. The frequency of variant alleles of the gene XPD 751GIn in persons of this group was increased compared with group II (0.49 and 0.39 , respectively), but the difference was not significant $(p=0.18)$.

The frequency of homozygous allele carriers Gln751GIn (among all other genotypes) in TC patients exposed to IR was significantly higher than in TC patients without IR exposure in history (Table 1) - 26.31\% and $9.38 \%$, respectively, $\chi^{2}=5.17, p=0.023$. The fre- 
quency of this genotype in a group of other categories of Chornobyl victims (evacuees and residents of contaminated territories) did not differ significantly $\left(x^{2}=\right.$ $0.11, p=0.74)$.

The OR was calculated in different models of inheritance (Table 2). When compared with a control group of Ukrainian population in homozygous carriers of the minor allele of the gene XPD Lys $751 \mathrm{GIn}$, exposed to IR, it was found a significantly increased risk of TC: OR = 3.66; $p=0.03$ (95\% Cl 1.04-12.84). When compared with a control group of Ukrainian population in patients without a history of exposure to IR, carrier state of homozygous minor alleles of the gene XPD Lys751GIn was not associated with risk of TC: $\mathrm{OR}=1.06 ; p=$ 0.93 (95\% Cl 0.28-4.00). In our research the IR was a factor that determined the high risk of TC depending on Lys751GIn XPD polymorphism.

Association analysis was performed between frequency of spontaneous chromosome aberrations in TC patients and XPD Lys751GIn polymorphism. The significant link of XPD Lys751GIn gene polymorphism with elevated chromosome aberrations was observed only in the group IB of TC patients evacuated and residents of contaminated areas in Ukraine. The average frequency of chromosome aberrations in patients with genotype Gln751GIn was significantly higher than in heterozygotes Lys751GIn $(5.35 \pm 1.19$ and $3.07 \pm 0.36$ aberrations/per 100 cells, respectively, $p=0.003$ ). Although a similar trend was observed in relation to Lys751Lys homozygotes, the difference in this case has insufficient level of certainty due to two times less sampling. Differences in frequency of chromosome- and chromatid-type aberrations depending on the genotype in this group were not found.

In participants of liquidation of the Chornobyl NPP accident consequences of group IA, in which the cytogenetic analysis was held, there were none individuals homozygous by the major allele XPD Lys751 Lys. The tendency to increase the frequency of aberrations in individuals with genotype Gln751GIn compared with heterozygotes XPD Lys751GIn was insufficient $(p=$ 0.58 ). In the group of TC patients, who did not have the impact of IR in history (group II), the individuals with genotype XPD Gln751GIn were not found. The tendency to increase the overall frequency of aberrations in heterozygotes XPD Lys751GIn compared with carriers of genotype XPD Lys751Lys is insignificant in this group $(p=0.19)$. However, TC patients without exposure to IR in history (group II) being homozygous $X P D$ Lys751Lys carriers were characterized by the significantly reduced frequency of chromosome-type aberrations ( $p=0.007$, Table 3 ).

Sal'nikova et al. [16] revealed that frequency of spontaneous aberrations of chromosomal type additively increased by rising the number of copies of the minor allele variants of $X P D{ }^{*} 2251 \mathrm{G}$ and ${ }^{\star} 862 \mathrm{~A}$. These authors also observed the elevated levels of $\gamma$-induced chromosome aberrations in carriers of major alleles of XRCC1 G1996A (Arg399GIn) and XRCC1 ${ }^{*}$ C589T (Arg194Trp) $(p=0.002)$ and minor allele $h O G G 1{ }^{*}$ C977G (Ser326Cys) $(p=$ 0.011 ) [12]. Another study demonstrated the $X P D$ Gln751GIn polymorphism association with increased levels of chromosomal aberrations in micronucleus test among radiologists and cardiologists, who carry out radiography $[13,14]$. Au et al. [15] observed that by $X$-rays and UV blood irradiation in volunteers, polymorphisms XPD 312Asn and XPD $751 \mathrm{Gln}$ were associated with increasing levels of chromatyd breaks compared to wild-type alleles $(p<0.05)$. Sal'nikova et al. found that frequency of spontaneous aberrations of chromosomal type in the liquidators of the Chornobyl accident increased in carriers of minor alleles of the XPD gene (loci 2251T $>\mathrm{G}$ and 862G $>A$ ) and "positive" genotypes of GSTM1-GSTT1 detoxification genes [17]. There was found the statistically significant increase of chromosomal aberrations in patients with lung cancer with polymorphic variants of the gene XPD $T / G$ and $G / G$ compared with T/T genotype [11]. In our study the carriage of homozygous minor allele XPD Gln751GIn of DNA repair gene was associated with increased levels of chromosomal instability in TC patients among evacuees and residents of contaminated areas. These patients, unlike the patients of the group IA, have been subjected to more prolonged exposure to the low doses of radiation. The results suggest a possible role for the violations of repair processes in the carriers of this genotype in the increased risk of TC development of cancer of the thyroid gland, especially in the conditions of chronic exposure to the low doses of radiation.

Table 3. Link of repair gene polymorphisms XPD Lys $751 \mathrm{Gln}$ with spontaneous level of chromosomal abnormalities in lymphocytes of peripheral blood in TC patients

\begin{tabular}{|c|c|c|c|c|c|c|c|c|}
\hline Groups, genotype & $\begin{array}{c}\text { Frequency } \\
\text { of aberrant cell }\end{array}$ & $p$ & $\begin{array}{c}\text { Frequency } \\
\text { of aberrations }\end{array}$ & $p$ & $\begin{array}{c}\text { Chromatyd-type } \\
\text { aberrations }\end{array}$ & $p$ & $\begin{array}{c}\text { Chromosome-type } \\
\text { aberrations }\end{array}$ & $p$ \\
\hline \multicolumn{9}{|c|}{ TC patients, group IA $(\mathrm{n}=10)$} \\
\hline Lys751Lys & - & & - & & - & & - & \\
\hline Lys751Gln & $2.44 \pm 0.91$ & & $2.79 \pm 0.97$ & & $2.44 \pm 0.91$ & & $0.35 \pm 0.34$ & \\
\hline Gln751Gln & $2.95 \pm 0.72$ & $p_{2}=0.67$ & $3.50 \pm 0.78$ & $\mathrm{p}_{2}=0.58$ & $2.21 \pm 0.63$ & $\mathrm{p}_{2}=0.83$ & $1.29 \pm 0.48$ & $\mathrm{p}_{2}=0.18$ \\
\hline \multicolumn{9}{|c|}{ TC patients, group IB ( $n=22)$} \\
\hline Lys751Lys & $3.00 \pm 0.76$ & & $3.41 \pm 0.81$ & & $2.20 \pm 0.65$ & & $1.20 \pm 0.48$ & \\
\hline Lys751Gln & $2.68 \pm 0.34$ & $\mathrm{p}_{3}>0.05$ & $3.07 \pm 0.36$ & $\mathrm{p}_{3}>0.05$ & $1.73 \pm 0.27$ & $\mathrm{p}_{3}>0.05$ & $1.34 \pm 0.24$ & $\mathrm{p}_{3}>0.05$ \\
\hline Gln751Gln & $4.51 \pm 1.10$ & $p_{1}=0.24$ & $5.35 \pm 1.19$ & $p_{1}=0.16$ & $3.10 \pm 0.91$ & $p_{1}=0.41$ & $2.25 \pm 0.78$ & $\mathrm{p}_{1}=0.23$ \\
\hline \multicolumn{3}{|c|}{ TC patients, group II $(n=10)$} & & $\mathrm{p}_{2}=0.03$ & & $\mathrm{p}_{2}=0.08$ & & $\mathrm{p}_{2}=0.18$ \\
\hline Lys751Lys & $1.85 \pm 0.49$ & & $1.98 \pm 0.50$ & & $1.85 \pm 0.49$ & & $0.13 \pm 0.13$ & \\
\hline $\begin{array}{l}\text { Lys751Gln } \\
\text { Gln751Gln }\end{array}$ & $\begin{array}{c}2.49 \pm 0.57 \\
-\end{array}$ & $\mathrm{p}_{3}=0.40$ & $\begin{array}{c}3.04 \pm 0.63 \\
-\end{array}$ & $\mathrm{p}_{3}=0.19$ & $\begin{array}{c}1.52 \pm 0.45 \\
-\end{array}$ & $p_{3}=0.62$ & $\begin{array}{c}1.52 \pm 0.45 \\
-\end{array}$ & $\mathrm{p}_{3}=0.007$ \\
\hline
\end{tabular}

Notes: $\mathrm{p}_{1}-\mathrm{G} \ln 751 \mathrm{Gln} v s$ Lys751Lys; $\mathrm{p}_{2}-\mathrm{Gln} 751 \mathrm{Gln} v s$ Lys751GIn; $\mathrm{p}_{3}-$ Lys751GIn vs Lys751Lys. 
It is not possible to estimate the influence of the aberrations frequency on the modification of the TC risk in the carriers of the Gln751GIn genotype, because in the Chornobyl NPP accident liquidators of the group IA the genotype XPD Lys751 Lys was not found. It should be noted the significant reduction of the mitotic index of the lymphocyte culture in the group IA patients in comparison with the other groups of patients. This resulted in the reduction of the frequency of aberrations in the total cell culture and the lack of the significant differences in the frequency of chromosomal aberrations between the carriers of the different genotypes in this group, compared with group IB.

\section{CONCLUSIONS}

In homozygous carriers of the minor allele of the gene $X P D \mathrm{Gln} 751 \mathrm{GIn}$, exposed to IR, there was found a significantly increased risk of TC with OR $=3.66, p=0.03(95 \%$ Cl 1.04-12.84) compared to a control group of Ukrainian population. In TC patients who were evacuees and residents of the areas contaminated with radionuclides, homozygous carriage of the minor allele variants $X P D$ Gln751Gln gene was associated with the increased levels of spontaneous chromosome aberrations.

\section{REFERENCES}

1. Wu X, Gu J, Grossman HB, et al. Bladder cancer predisposition: a multigenic approach to DNA-repair and cell-cycle-control genes. Am J Hum Genet 2006; 78: 464-79.

2. Qiu LX, Yao L, Zhang J, et al. XPD Lys751Gln polymorphism and breast cancer susceptibility: a meta-analysis involving 28,709 subjects. Breast Cancer Res Treat 2010; 124: 229-35.

3. Zhuravleva YA, Minina VI, Titov RA, et al. Polymorphism of reparation enzymes DNA genes of patients with lung cancer. Siberian J Oncol 2012; (Suppl 1): 68 (in Russian).

4. Yang B, Chen WH, Wen XF, et al. Role of DNA repairrelated gene polymorphisms in susceptibility to risk of prostate cancer. Asian Pac J Cancer Prev 2013; 14: 5839-42.

5. Procopciuc LM, Osian G. Lys751Gln XPD and Arg399GIn XRCC1 in Romanians. Association with sporadic colorectal cancer risk and different stages of carcinomas. Chirurgia (Bucur) 2013; 108: 711-8.

6. Tao W, Haitao W, Hongyun G, et al. Polymorphisms in the DNA repair gene $E R C C 2 / X P D$ and breast cancer risk: a hapmap-based case - control study among Han women in a Chinese less-developed area. Genet Test Mol Biomarkers 2014; 18: 703-10.

7. Ashraf R, Kadla SA, Wani HA, et al. Gastric cancer risk and XPD/ERCC2 SNPS (LYS751GLN, ASP312ASN) gene polymorphism - an Experimental study in Kashmir Valley of India. Eur Acad Res 2015; II: 14146-59.

8. Chumak AA, Belous NI, Abramenko IV, Costin AV. Effect of genes polymorphisms, encoding repair proteins of DNA, on the risk of developing chronic lymphocytic leukemia in liquidators of the Chornobyl disaster. Sci Bull Uzhgorod Univ (Ser Biol) 2010; (27): 210-5 (in Ukrainian).

9. Sliwinski T, Krupa R, Wisniewska-Jarosinska M, et al. Common polymorphisms in the XPD and hOGG1 genes are not associated with the risk of colorectal cancer in a Polish population. Tohoku J Exp Med 2009; 218: 185-91.

10. Manuguerra $M$, Saletta $F$, Karagas $M R$, et al. XRCC 3 and XPD/ERCC2 single nucleotide polymorphisms and the risk of cancer: a HuGE review. Am J Epidemiol 2006; 164: $297-302$.

11. Bakanova ML, Minina VI, Savchenko YA, et al. Association of of the polymorphism of DNA-repair genes with chromosomal aberrations in lung cancer patients. Mol Genet Microbiol Virol 2013; 28: 3-6 (in Russian).

12. Sal'nikova LE, Akaeva EA, Elisova TV, et al. The effect of polymorphism of genes of xenobiotics detoxication on the frequencies of spontaneous and induced chromosome aberrations in human lymphocytes. Radiats Biol Radioecol 2009; 49: 543-51 (in Russian).

13. Andreassi MG, Foffe I, Manfredi S, et al. Genetic polymorphisms in XRCC1, OGG1, APE1 and XRCC3 DNA repair genes, ionizing radiation exposure and chromosomal DNA damage in interventional cardiologists. Mutat Res 2009; 666: $57-63$.

14. Cho YH, Kim YJ, An YS, et al. Micronucleus-centromere assay and DNA repair gene polymorphism in lymphocytes of industrial radiographers. Mutat Res 2009; 680: 17-24.

15. Au WW, Salama SA. Cytogenetic challenge assays for assessment of DNA repair capacities. Methods Mol Biol 2006; 314: 25-42.

16. Sal'nikova LE, Chumachenko AG, Vesnina IN, et al. Polymorphism of repair genes and cytogenetic radiation effects. Radiats Biol Radioecol 2010; 50: 656-62 (in Russian).

17. Sal'nikova LE, Chumachenko AG, Lapteva NS. Allelic variants of polymorphic genes combined with the increased frequency of chromosomal aberrations. Genetics 2011; 47 (10): 117-25 (in Russian).

18. Minina VI. Genetic polymorphism and chromosome aberrations induced by radiation. Siber Med J 2012; (3): 5-7 (in Russian).

19. Demina EA. The problem of radiogenic thyroid cancer. Science Rise 2015; (2/4 (7)): 23-30 (in Russian).

20. Shkarupa VM, Henyk-Berezovska SO, Palamarchuk VO, et al. Research of DNA repair genes polymorphism $X R C C 1$ and $X P D$ and the risks of thyroid cancer development in persons exposed to ionizing radiation after Chornobyl disaster. Probl Radiat Med Radiobiol 2015; (20): 552-71. 